\title{
RURAL TERRITORY DIFFERENTIATION ACCORDING TO THE ECOLOGICAL CRITERIA FOR THE RYAZAN REGION
}

\author{
Irina Andriyanova ${ }^{1}$, MA, Inna Davydova², Dr.sc., assoc.prof. and Yury Mazhayskiy ${ }^{3}$, \\ Dr.sc., prof. \\ ${ }^{1,2}$ Ryazan State University named after S.A. Yesenin, Russia; ${ }^{3}$ Meshchersky branch All-Russian Research \\ Institute of Hydrotechnics and Melioration named after A.N. Kostyakova, Russia
}

\begin{abstract}
Increased industrial enterprises concentration leads to environmental pollution in rural areas and an increase in incidence. This problem was studied using spatial comparative analysis. There was determined the negative trend value for rural development. A comparison of rural areas was made in the Ryazan region. These areas are similar in terms of natural conditions and differ in terms of economic development and health risks. Medical and demographic statistics were used to justify the impact of environmental pollution on the rural population morbidity. Statistical indicators of rural population morbidity and mortality based on medical data were used. The environment pollution influence on the growth of neoplasm morbidity and mortality has been established for rural areas. These indicators are higher in the Ryazan region than the average for Russia. The indicator of social factors, which is the main cause of infectious disease death from in $60 \%$ of cases, was chosen as the tuberculosis morbidity and mortality rate. To calculate the integral region health index there were used environmentally significant pathology indicators - the neoplasm incidence index, the neoplasm mortality index and the infant mortality index. The tuberculosis mortality index was used as the negative social phenomena indicator. The ranking of municipalities (mostly rural) was based on these indexes. Intraregional differentiation of the population's health status largely corresponds to the distribution of background territory pollution indicators. Therefore territorial and temporal changes in the integral index of regional health should be considered as an indicator of the corresponding negative environment quality change.
\end{abstract}

Key words: population morbidity, integral regional health index, rural territory classification, environment quality.

JEL code: I1

\section{Introduction}

The environmental impact of rural localities is determined by their functional type and population size. For the Ryazan region the main type of rural settlements is the agricultural type. As a rule this is characterized by terrain transformation, soil degradation and contamination, underground and surface water pollution (Mazhayskiy, 2001). The maximum anthropogenic load associated with agricultural activity is confined to the territories of agricultural settlements with a population of more than 500. The settlement system, being a subject of environmental "pressure", in turn, experiences the impact of an adverse environmental situation through the health of the population (Lyapkalo, 2001). There is the increase in the incidence of circulatory system, respiratory organs, malignancies and endocrine system among the population in the Ryazan region (Kovalchuk, 2009). The sustainable development concept, adopted in Rio de Janeiro in 1992, was a turning point in the understanding of the importance of preserving a favourable environment and public health. Inequality in the health status of the population is observed in different territories (Meng, 2018). Zonal differences in health levels have long been established in the scientific literature and many studies confirm that people have different diseases in different geographical areas (Chenjing, 2019). Recently geographical issues have become increasingly intertwined with public health issues. For example there was built a set of conceptual frameworks that synthesized the relationship between health and various factors such as health, social policy, economy, consumption, environmental environment, and other factors that have a strong impact on people's health (Curtis, 2004). A number of empirical studies have

\footnotetext{
Irina Andriyanova. Tel.: +79105782449. E-mail address: irina.slepcova.86@mail.ru

2 Inna Davydova. Tel.: +79066474924. E-mail address: diu2004@mail.ru

3 Yury Nazhayskiy. Tel.: +79156013089. E-mail address: director@mntc.pro
} 
shown that environmental impacts and the uneven distribution of medical resources due to geographical conditions have caused public health problems (WHO, 2012; Lamnisos, 2019). In Russian practice medical and geographical issues are most thoroughly studied in the works performed under the supervision of S. M. Malhazova (Malhazova, 2001). In addition, medico-geographical mapping and modeling are reflected in the research of B. B. Prokhorov and V. S. Tikunov (Prohorov, Tikunov, 2005), as well as S. A. Kurolap (Kurolap, 2012) and other authors who study human ecology, public health and medical-ecological forecasting.

The purpose of our study was to develop a classification of rural areas based on several indicators and compare the state of the environment and the health of the population living in a particular area. One of the methodological approaches to identifying trends in environmental conditions is a spatialcomparative analysis of individual territories. It is based on the opposition of territorial complexes (systems) of the same type in terms of natural conditions, but differing in the degree of their economic development and the risk of a certain disease. To identify the relationship between the state of the environment and the health of the population, a system of the method of scoring with subsequent calculations was used. This methodological approach allows us to determine the degree of negative trends and their significance for rural development. A comparison was made of rural areas that are similar in terms of natural conditions, but differ in terms of economic development and health risks. Medical and demographic statistics were used to justify the impact of environmental pollution on the incidence of rural population. Statistical indicators of morbidity and mortality of the rural population based on medical data were used.

\section{Research results and discussion}

When creating a typology usually it is necessary to solve the problem of optimal selection of initial indicators that should comprehensively characterize the essence of the phenomenon under study. Obviously for health estimate in a region it is appropriate to use indicators of morbidity and mortality associated with a disease that depends on the degree of pollution of the environment with toxic substances. It was found that the indicators of neoplasm morbidity and mortality are the most informative when comparing the Ryazan region and the average situation in Russia. These indicators shows the impact of negative geological and ecological (or geo-ecological) factor such as chemical pollution of the environment. The indicator of tuberculosis morbidity and mortality was chosen because it depends on social factors. Tuberculosis is the main cause of death from infectious diseases in $60 \%$ of cases. To calculate the regional health integral index we selected some indicators. Firstly they were connected with environmentally significant pathologies such as the neoplasm incidence and neoplasm mortality. Secondly we used the tuberculosis morbidity and the tuberculosis mortality as the indicators of negative social phenomena. Thirdly the infant mortality has been selected because it is considered reliable indicator of the interaction of the environmental situation on the health of the population (Semenova, 2010).

The regional health integral index $(R H I I)$ was calculated using the formula (1):

$$
R H I=1 \mathrm{I} \frac{I d n+I d t+I m n+I m t+\operatorname{Iim}}{\mathbf{5}}
$$

Where:

$I d n$ - is the neoplasm morbidity index;

Idt - is the tuberculosis morbidity index;

Imn - is the neoplasm mortality index; 
Imt - is the tuberculosis mortality index;

Iim - is the infant mortality index.

To calculate the Idn as the other indexes - the Idt, the Imn, Imt and Iim - for each (i-th) district during the period from 2005 to 2010 the formula (2) was used:

$$
I d n=\frac{X i a v-X i m i n}{X \max -X \min }
$$

Where:

Xiav - is the average value of the neoplasm morbidity rate for each (i-th) district;

Ximin - is the minimum value of the neoplasm morbidity rate for each ( $\mathrm{i}$-th) district;

$X \max$ - is the maximum value of the neoplasm morbidity rate for all districts in the region;

$X \min$ - is the minimum value of the neoplasm morbidity rate for all districts in the region (based on Prohorov, Tikunov, 2005).

To calculate the indexes the data concerning the neoplasm morbidity rate, the tuberculosis morbidity rate, the neoplasm mortality rate, the tuberculosis mortality rate and the infant mortality rate were taken from official sources (Gosudarstvennyy doklad, 2014). The results of calculating the RHII values are shown in table 1.

Table 1

\section{The regional health integral index (RHII) for municipalities of the Ryazan region}

\begin{tabular}{|c|c|c|c|c|c|}
\hline No & Municipality & $\begin{array}{l}\text { Regional } \\
\text { health } \\
\text { integral } \\
\text { index }\end{array}$ & No & Municipality & $\begin{array}{c}\text { Regional } \\
\text { health } \\
\text { integral } \\
\text { index }\end{array}$ \\
\hline 1. & Ryazan city & 0.40 & 14. & Rybnovsky district & 0.60 \\
\hline 2. & Yermishinsky district & 0.52 & 15. & Ryazhsky district & 0.46 \\
\hline 3. & Zakharovsky district & 0.55 & 16. & Ryazan district & 0.40 \\
\hline 4. & Kadomsky district & 0.45 & 17. & Sapozhkovsky district & 0.60 \\
\hline 5. & Kasimov district & 0.40 & 18. & Sarajevo district & 0.56 \\
\hline 6. & Klepikovsky district & 0.50 & 19. & Sasovskiy district & 0.54 \\
\hline 7. & Ship district & 0.63 & 20. & Skopinsky district & 0.52 \\
\hline 8. & Miloslavsky district & 0.60 & 21. & Spassky district & 0.50 \\
\hline 9. & Mikhailovsky district & 0.40 & 22. & Starozhilovsky district & 0.53 \\
\hline 10. & Novoderevensky district & 0.65 & 23. & Uholovsky district & 0.50 \\
\hline 11. & Pitelinsky district & 0.70 & 24. & Chuchkovsky district & 0.54 \\
\hline 12. & Pronsky district & 0.57 & 25. & Shatsky district & 0.60 \\
\hline 13. & Putyatinsky district & 0.60 & 26. & Shilovsky district & 0.57 \\
\hline
\end{tabular}

Source: author's calculations based on Gosudarstvennyy doklad, 2014; Sleptsova, 2012

The value of the RHII varies from zero to one. Zero corresponds to the worst estimate, one to the best state. The RHII values are concentrated in the range 0.4-0.7. The results of classification of districts of the Ryazan region by the level of population health are shown in figure 1 . The first group, characterized by a generally healthy level of health, includes 2 districts of the study region. Here, the RHII is maximum and has a value of at least 0.7 and 0.65 , respectively. The second, most numerous group, characterized by a satisfactory level of health of the population (the RHII in the range of $0.56-0.60$ ) includes eight districts. The group with a low level of regional health includes the territories of 5 municipal districts which are characterized by the RHII within 0.52-0.56.

The group with a low level of regional health includes the territories of 5 municipal districts with the RHII in the range of $0.46-0.52$. As a result of the analysis, 6 territories were assigned to the group with a poor level of population health. They are the regional centre Ryazan and Ryazhsky, Kadomsky, Kasimovsky and Mikhailovsky districts (the RHII within 0.40 - 0.46). The typological classification of the territory of the region by medical and geographical indicators allowed us to 
identify areas with an unfavourable medical and geographical situation, which requires more attention to them, administrative bodies, health authorities and environmental organizations. Areas with adverse conditions require more detailed research to determine the cause of their occurrence.

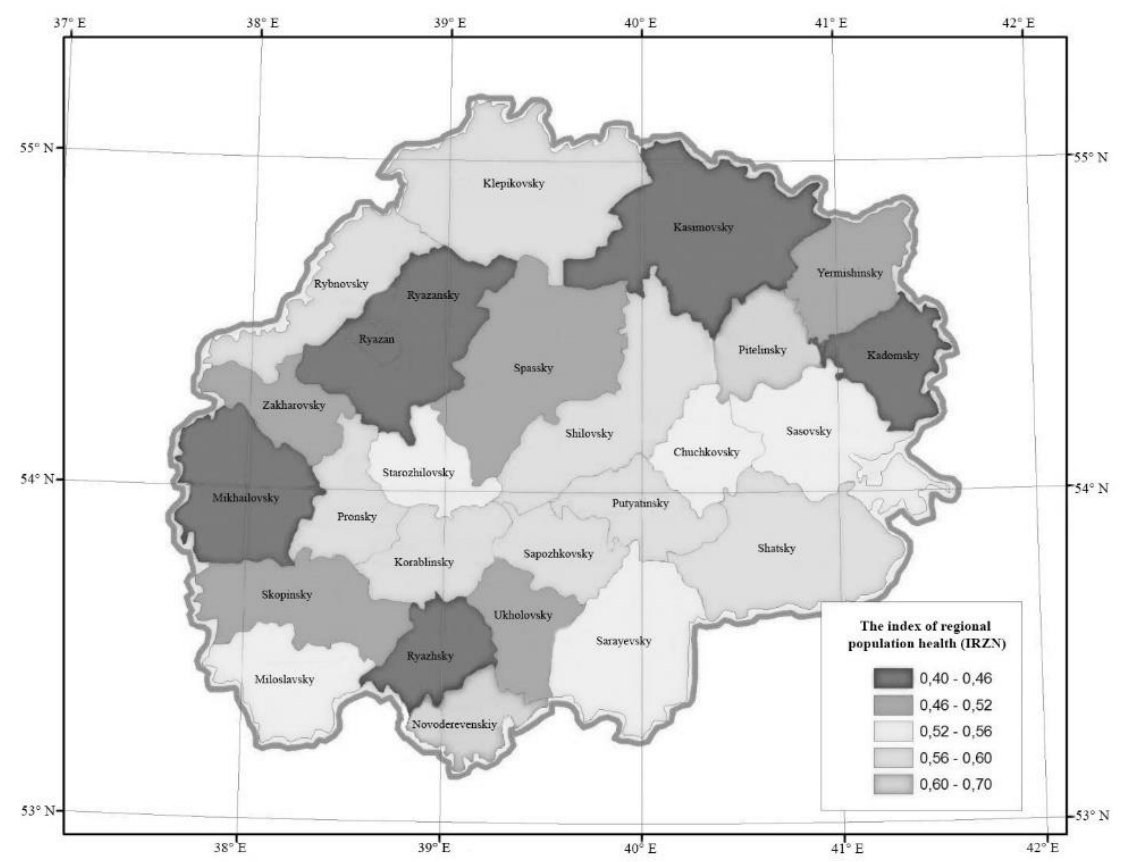

Source: author's calculations based on Gosudarstvennyy doklad, 2014; Semenova, 2010

Fig. 1. The population health status for municipal districts of the Ryazan region

To identify depending on the level of regional health from negative environmental effects, the combined ranking for districts in the Ryazan region was made in 2010. The two indicators were used for this purpose - the RHII and the integral indicator of assessment of geo-ecological situation in the region. It should be noted that the integral indicator of assessment of geo-ecological situation in the region was calculated earlier (Sleptsova, 2012). Table 2 shows the results of the study. 


\section{Combined ranking of the territory of the studied region by the size of the RHII and the geo-ecological situation in the Ryazan region}

\begin{tabular}{|c|c|c|c|c|c|c|c|}
\hline No & Municipality & $\begin{array}{c}\text { Integral assessment of the } \\
\text { geo-ecological situation in } \\
\text { the region }\end{array}$ & $\begin{array}{c}\text { Regional } \\
\text { health } \\
\text { integral index }\end{array}$ & No & Municipality & $\begin{array}{c}\text { Integral } \\
\text { assessment of } \\
\text { the } \\
\text { geo-ecological } \\
\text { situation in } \\
\text { the region } \\
\end{array}$ & $\begin{array}{c}\text { Regional } \\
\text { health } \\
\text { integral index }\end{array}$ \\
\hline 1. & Ryazan city & critical & 0.40 & 14. & $\begin{array}{l}\text { Rybnovsky } \\
\text { district }\end{array}$ & tense & 0.60 \\
\hline 2. & $\begin{array}{l}\text { Yermishinsky } \\
\text { district }\end{array}$ & satisfactory & 0.52 & 15. & $\begin{array}{l}\text { Ryazhsky } \\
\text { district }\end{array}$ & tense & 0.46 \\
\hline 3. & $\begin{array}{l}\text { Zakharovsky } \\
\text { district }\end{array}$ & satisfactory & 0.52 & 16. & Ryazan district & critical & 0.40 \\
\hline 4. & Kadomsky district & satisfactory & 0.45 & 17. & $\begin{array}{l}\text { Sapozhkovsky } \\
\text { district }\end{array}$ & favourable & 0.60 \\
\hline 5. & Kasimov district & spicy & 0.40 & 18. & Sarajevo district & favourable & 0.56 \\
\hline 6. & $\begin{array}{l}\text { Klepikovsky } \\
\text { district }\end{array}$ & tense & 0.58 & 19. & $\begin{array}{l}\text { Sasovskiy } \\
\text { district }\end{array}$ & tense & 0.54 \\
\hline 7. & $\begin{array}{l}\text { Korablinsky } \\
\text { district }\end{array}$ & tense & 0.60 & 20. & $\begin{array}{l}\text { Skopinsky } \\
\text { district }\end{array}$ & tense & 0.52 \\
\hline 8. & $\begin{array}{l}\text { Miloslavsky } \\
\text { district }\end{array}$ & satisfactory & 0.54 & 21. & Spassky district & spicy & 0.50 \\
\hline 9. & $\begin{array}{l}\text { Mikhailovsky } \\
\text { district }\end{array}$ & critical & 0.45 & 22. & $\begin{array}{l}\text { Starozhilovsky } \\
\text { district }\end{array}$ & tense & 0.53 \\
\hline 10. & $\begin{array}{l}\text { Novoderevensky } \\
\text { district }\end{array}$ & favourable & 0.65 & 23. & $\begin{array}{l}\text { Uholovsky } \\
\text { district }\end{array}$ & favourable & 0.50 \\
\hline 11. & Pitelinsky district & favourable & 0.70 & 24. & $\begin{array}{l}\text { Chuchkovsky } \\
\text { district }\end{array}$ & tense & 0.54 \\
\hline 12. & Pronsky district & critical & 0.57 & 25. & Shatsky district & tense & 0.60 \\
\hline 13. & $\begin{array}{l}\text { Putyatinsky } \\
\text { district }\end{array}$ & tense & 0.60 & 26. & $\begin{array}{l}\text { Shilovsky } \\
\text { district }\end{array}$ & spicy & 0.57 \\
\hline
\end{tabular}

Source: author's calculations based on Gosudarstvennyy doklad, 2014; Sleptsova, 2012

The analysis showed that for the first group of municipalities, characterized by a relatively good state of health, corresponds to favourable environmental situation for the second group with satisfactory levels of health - satisfactory and ecological situation, for the group of districts with low level of regional health characterized by acute and serious ecological situation in the group with low level of regional health - a tense and acute ecological situation in the group with unfavorable levels of health are mainly dominated by acute and critical environmental situation.

Standard procedures for spatial analysis in GIS were used to obtain quantitative estimates that characterize the above relationships and to solve the problem of zoning the territory of the Ryazan region according to the degree of influence of geo-ecological factors on the health of the population. In particular, thematic maps describing the geo-ecological situation and health status of the population of municipal districts of the Ryazan region, presented in vector form, were converted to raster. Further, a reclassification procedure was carried out, as a result of which the information presented on the maps was brought to a single scale (10 classes in each, ranked by increasing environmental and health burden and deterioration, respectively), which allowed a wide range of operations to be performed with them in the future. In particular, a raster layer overlay (subtraction) operation was performed, which resulted in a scheme reflecting the degree of overlap of classes that characterize the environment and health for each district.

Analysis of the data shown in the diagram shows a significant causation of the incidence of the current environmental situation. So, in 5 districts, a complete match of classes is found. In 12 districts, there is a discrepancy of 1 class (with 4 maximum possible). 


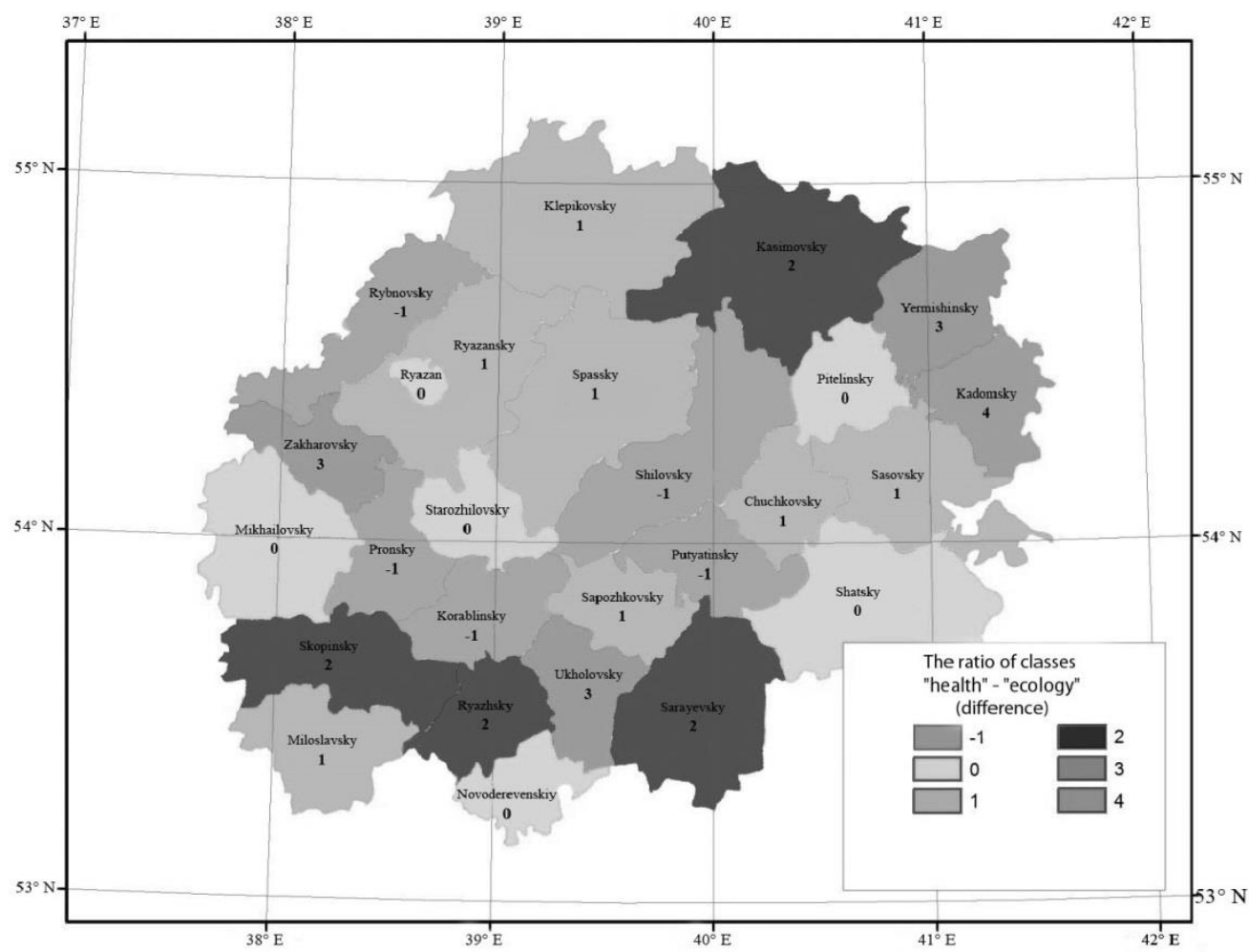

Source: author's calculations based on Gosudarstvennyy doklad, 2014; Prohorov, Tikunov, 2005

Fig. 2. Zoning of the Ryazan region territory according to the degree of influence of geoecological factors on the population health

Consequently, for 17 districts of the Ryazan region out of 26 (65.4\%), the existence of a significant link between the environmental situation and the health of the population has been proven. At the same time, the connection of these characteristics is more evident in areas with a complex environmental situation and is typical for territories located in the Central and Eastern parts of the region. The largest deviations from the General trend ( 2 or more classes) are typical for districts located in the North-Western and southern parts of the region. Here, the health status of the population is significantly worse than could be predicted based on an assessment of the environmental situation. It is obvious that several other factors and processes are of decisive importance in these areas.

\section{Conclusions and suggestions}

Thus, the carried out zoning of the territory of the Ryazan region according to the degree of influence of environmental factors on the health status of rural population leads to the conclusion that intra-regional differentiation of the health status of the population largely corresponds to distribution of background pollution of the area that allows geographically-temporal changes of the index of regional population health regarded as the appropriate indicator of changes in environmental quality. When establishing the connection between these indicators based on medical and demographic statistics, it is concluded that the quality of the human environment is decreasing and this decrease is a negative result of economic activity.

\section{Bibliography}

1. Curtis, S. (2004). Health and Inequality: Geographical Perspectives; Sage: Thousand Oaks, CA, USA.

2. Chenjing, F., Wei, O., Li, T., Yan, S. and Wensheng, M. (2019). Elderly Health Inequality in China and its Determinants: A Geographical Perspective. International Journal of Environmental Research and Public.

3. Gosudarstvennyy doklad (2014). O sanitarno-epidemiologicheskoy obstanovke $\vee$ Ryazanskoy oblasti v 2016 godu. // Ryazan'. Rospotrebnadzor. - 120 p. 
4. Kiryushin, V. A., Konopleva, V. I., Akutin, E. K., Kuzina, N. A. (2002). Frequency of Isolation and Species Composition of Pathogens of Intestinal Infections in Open Water. Microbiology and Biotechnology of the XXI Century. Materials of the International Conference. Minsk: Mikrobio. - 41 p.

5. Kovalchuk, T. U. (2009). Gigiyenicheskaya otsenka sostoyaniya atmosfernogo vozdykha I zdorov'ya naseleniya prigorodnykh zon promyshlennogo tsentra. Ryazan'. - 237 p.

6. Kurolap, S. A., Klepikov, O. V. (2012). Integral'noe mediko-ehkologicheskoe zonirovanie kak osnova regional'noj strategii ustojchivogo razvitiya Voronezhskogo regiona / S. A. Kurolap, O. V. Klepikov. // Vestnik Tambovskogo universiteta. Ser. Estestvennye i tekhnicheskie nauki. No 2, pp. 516-519.

7. Lamnisos, D., Middleton, N. (2019). Geodemographic Area Classification and Association with Mortality: An Ecological Studyof Small Areas of Cyprus, Tom 16, Release 16, No 2927.

8. Lyapkalo, A. A., Dementiev, A. A., Tsurgan, A. M. (2001). Risk dopolnitel'nykh smertey ot vozdeystviya vzveshennykh $\vee$ gorodakh tsentral'noy Rossii. Upravleniye riskam chrezvychynykh situtsiy. / Shestaya Vserossiyskaya nauchno-practicheskaya konferentsiya. Moskva, pp. 338-340.

9. Mazhayskiy, Yu. A., Evtyukhin, V. A., Reznikova, A. V. (2001). Ekologiya agrolandshafta Ryazanskoy oblasti. Monografiya. M.: Izdatel'sstvo MGU. - 93 p.

10. Malhazova, S. M. (2001). Mediko-geograficheskij analiz territorij: kartografirovanie, otcenka, prognoz. / M.: Nauchnyj mir. - 240 p.

11. Meng, L., Huang, J. (2018). Assessment of Rural Ecosystem Health and Type Classification in Jiangsu Province. China. Volume 615, pp. 1218-1228.

12. Prohorov, B. B., Tikunov, V. S. (2005). Mediko-demograficheskaya klassifikaciya regionov Rossii // Problemy prognozirovaniya. No 5, pp. 142-152.

13. Semenova, A. N. (2010). Analiz sostoyaniya zdorov'ya naseleniya Krasnodarskogo kraya: geograficheskiy aspect. Krasnodar, $160 \mathrm{p}$.

14. Sleptsova, I. N. (2012). Integral'naya otcenka geoecologicheskoy situatcii v Ryazanskoy oblasti. / Byulleten' Moskovskogo Gosudarstvennogo Oblastnogo universiteta. No. 2, p. 97-100.

15. The World Health Organization (2012). Environmental Health Inequalities in Europe. Retrieved: http://www.euro.who.int/_data/ assets/pdf_file/0010/157969/e96194.pdf. Access: 10.02.2020. 